\title{
Nanošenje fotokatalitičkih ZnO slojeva na podloge različite geometrije
}

\author{
J. Macan, ${ }^{a}{ }^{*}$ M. Kovačević, ${ }^{a}$ M. Lipovski, ${ }^{a}$ M. Medića i I. Grčićb \\ Sveučilište u Zagrebu, Fakultet kemijskog inženjerstva i tehnologije, \\ Marulićev trg 19, 10000 Zagreb, Hrvatska \\ ๖ Sveučilište u Zagrebu, Geotehnički fakultet, Hallerova aleja 7, 42000 Varaždin, Hrvatska
}

Ovo djelo je dano na korištenje pod

\author{
Sažetak \\ Ispitivan je način priprave fotokatalitički aktivnog ZnO sloja taloženjem iz otopine. Slojevi bazičnog cinkova acetata (LBZA) \\ uspješno su naneseni na podloge različitih morfologija, a prethodna hidroliza podloge pogoduje dobivanju debljih i čvršće \\ vezanih slojeva. No postupak priprave znatno je osjetljiv na varijacije u uvjetima što čini prevlačenje većih površina zahtjev- \\ nijim. Reproducibilnost fotokatalitičke aktivnosti ZnO slojeva dobivenih žarenjem LBZA slaba je i varira do $50 \%$, bez jasne \\ pravilnosti.

\section{Ključne riječi} \\ Cinkov oksid, fotokatalitička razgradnja, kemijsko taloženje iz otopine, mikrostruktura, modifikacija površine
}

\section{Uvod}

Cinkov oksid poznati je poluvodički materijal koji je privukao poroznost radi potencijalne primjene u fotonaponskim ćelijama i kao fotokatalizator. ${ }^{1-4}$ Za obje primjene poželjno je nanošenje $\mathrm{ZnO}$ u obliku sloja dobro vezanoga na podlogu. $U$ ovom radu proučavano je kemijsko taloženje iz otopine (engl. chemical bath deposition, CBD), čije su prednosti jednostavnost, niska cijena i blagi reakcijski uvjeti. Čvrste prevlake nastaju uranjanjem podloga u otopinu metalnih soli, u kojoj se pri blago povišenim temperaturama odvijaju tri reakcijska koraka: (1) nastajanje solvatiziranih ionskih kompleksa metala, (2) hidroliza kompleksa i (3) nastanak čvrstih faza, najčešće heterogenom nukleacijom na površini podloge. ${ }^{5}$

Odabran je postupak taloženja iz metanolne otopine cinkova acetata dihidrata. Poznato je da pri tome nastaje slojeviti bazični cinkov acetat, $\mathrm{Zn}_{5}(\mathrm{OH})_{8}\left(\mathrm{CH}_{3} \mathrm{COO}\right)_{2} \cdot 2 \mathrm{H}_{2} \mathrm{O}$ (engl. layered basic zinc acetate, LBZA), koji zatim žarenjem prelazi u ZnO zadržavajući listićavu morfologiju LBZA. ${ }^{5-10}$ Hidrotermalna sinteza alternativni je pristup pripravi slojeva sličnih morfologija, ${ }^{11-14}$ no preliminarna istraživanja pokazuju da su takvi slojevi vrlo prhki i znatno slabije vezani na nemodificiranu podlogu od slojeva iz metanolne otopine. Prethodno ${ }^{15}$ su ustanovljeni optimalni uvjeti za dobivanje karakteristične cvjetaste morfologije $\mathrm{ZnO}$. U ovom radu ispitivana je ponovljivost postupka, utjecaj dodatka vode u otopinu, volumena otopine te oblika i prethodne obrade podloge na koju se slojevi nanose.

\footnotetext{
*Autor za dopisivanje: prof. dr. sc. Jelena Macan e-pošta: jmacan@fkit.hr
}

\section{Eksperimentalni dio}

\subsection{Priprava prevlaka}

Pripravljene su otopine cinkova acetata dihidrata (Sigma-Aldrich) u metanolu (Honeywell) koncentracije $0,15 \mathrm{~mol} \mathrm{dm}^{-3}$, te su slojevi nanošeni kristalizacijom iz otopine $41 \mathrm{~h}$ pri $55{ }^{\circ} \mathrm{C}$. Radi ispitivanja utjecaja vode na kristalizaciju u otopinu je dodana deionizirana voda u množinskom omjeru 2:1 prema cinku. Utjecaj volumena otopine proučavan je udvostručivši volumen otopine koja je u kontaktu s podlogom za vrijeme nanošenja.

Za praktičnu primjenu $\mathrm{ZnO}$ fotokatalizatora zanimljivo ga je nanositi na mrežaste podloge ili tkanine, radi povećanja površine u dodiru s otopinom, kao i na unutarnju stijenku cijevnih reaktora. Stoga je ispitivano nanošenje prevlaka na različite oblike staklenih podloga: predmetno stakalce, staklena mrežica, staklena tkanina, unutrašnjost staklene bočice i unutrašnjost staklene vijalice. Predmetno stakalce, bočice i vijalice prethodno su oprane detergentom te isprane destiliranom vodom i etanolom. S mrežica i tkanina zaštitni organski sloj (apretura) uklonjen je žarenjem na $500{ }^{\circ} \mathrm{C}$, jer ga nije bilo moguće adekvatno ukloniti organskim otapalima.

Prevlake nanesene kristalizacijom iz otopine razmjerno se slabo vežu na površinu stakla, te je u nekim slučajevima zamijećeno odvajanje komada prevlake od podloge. Prisutnost hidroksilnih skupina na površini stakla utječe na kristalizaciju ZnO prilikom taloženja iz otopine. ${ }^{16,17}$ Stoga je proučavan utjecaj modifikacije površine stakla hidrolizom ili žarenjem, čime se povećava odnosno smanjuje pokrivenost površine podloge hidroksilnim skupinama, na formiranje i prianjanje prevlake. Hidroliza je provedena naizmjeničnim uranjanjem u vodene otopine $\mathrm{HCl}$ (Kemika) 
Tablica 1 - Uvjeti modifikacije podloge i masa nastalog sloja

Table 1 - Substrate modification conditions and the mass of formed layer

\begin{tabular}{|c|c|c|}
\hline $\begin{array}{l}\text { Uzorak } \\
\text { Sample }\end{array}$ & $\begin{array}{l}\text { Podloga i uvjeti modifikacije } \\
\text { Substrate and modification conditions }\end{array}$ & $\begin{array}{c}m(\text { sloj }) / m \text { (podloga), } \mathrm{mg} / \mathrm{g} \\
m \text { (layer) } / m \text { (substrate), } \mathrm{mg} / \mathrm{g}\end{array}$ \\
\hline p0 & $\begin{array}{l}\text { predmetno stakalce, bez modifikacije } \\
\text { glass slide, no modification }\end{array}$ & 6,0 \\
\hline$p Z$ & $\begin{array}{l}\text { predmetno stakalce, prethodno žarenje pri } 500{ }^{\circ} \mathrm{C} \\
\text { glass slide, calcined at } 500{ }^{\circ} \mathrm{C}\end{array}$ & 5,9 \\
\hline $\mathrm{pH}$ & $\begin{array}{l}\text { predmetno stakalce, prethodna hidroliza u } 0,1 \mathrm{M} \mathrm{HCl} \text { i } \\
\mathrm{NaOH} \\
\text { glass slide, hydrolysis in } 0.1 \mathrm{M} \mathrm{HCl} \text { and } \mathrm{NaOH}\end{array}$ & 6,3 \\
\hline $\mathrm{mo}$ & $\begin{array}{l}\text { staklena mrežica, bez modifikacije } \\
\text { glass mesh, no modification }\end{array}$ & 117,0 \\
\hline $\mathrm{mZ}$ & $\begin{array}{l}\text { staklena mrežica, prethodno žarenje pri } 500{ }^{\circ} \mathrm{C} \\
\text { glass mesh, calcined at } 500{ }^{\circ} \mathrm{C}\end{array}$ & 26,4 \\
\hline $\mathrm{mH}$ & $\begin{array}{l}\text { staklena mrežica, prethodna hidroliza u } 0,1 \mathrm{M} \mathrm{HCl} \text { i NaOH } \\
\text { glass mesh, hydrolysis in } 0.1 \mathrm{M} \mathrm{HCl} \text { and } \mathrm{NaOH}\end{array}$ & 192,5 \\
\hline b0 & $\begin{array}{l}\text { staklena bočica, bez modifikacije } \\
\text { glass bottle, no modification }\end{array}$ & 2,8 \\
\hline bZ & $\begin{array}{l}\text { staklena bočica, prethodno žarenje pri } 500{ }^{\circ} \mathrm{C} \\
\text { glass bottle, calcined at } 500{ }^{\circ} \mathrm{C}\end{array}$ & 2,5 \\
\hline $\mathrm{bH}$ & $\begin{array}{l}\text { staklena bočica, prethodna hidroliza u } 0,1 \mathrm{M} \mathrm{HCl} \text { i NaOH } \\
\text { glass bottle, hydrolysis in } 0.1 \mathrm{M} \mathrm{HCl} \text { and } \mathrm{NaOH}\end{array}$ & 5,6 \\
\hline to & $\begin{array}{l}\text { staklena tkanina, bez modifikacije } \\
\text { glass cloth, no modification }\end{array}$ & 151,0 \\
\hline $\mathrm{tH}$ & $\begin{array}{l}\text { staklena tkanina, prethodna hidroliza u } 0,1 \mathrm{M} \mathrm{HCl} \text { i NaOH } \\
\text { glass cloth, hydrolysis in } 0.1 \mathrm{M} \mathrm{HCl} \text { and } \mathrm{NaOH}\end{array}$ & 51,1 \\
\hline v0 & $\begin{array}{l}\text { staklena vijalica, bez modifikacije } \\
\text { glass vial, no modification }\end{array}$ & 3,4 \\
\hline $\mathrm{vH}$ & $\begin{array}{l}\text { staklena vijalica, prethodna hidroliza u } 0,1 \mathrm{M} \mathrm{HCl} \text { i NaOH } \\
\text { glass vial, hydrolysis in } 0.1 \mathrm{M} \mathrm{HCl} \text { and } \mathrm{NaOH}\end{array}$ & 2,6 \\
\hline
\end{tabular}

i $\mathrm{NaOH}$ (Lach-ner) koncentracija 0,1 $\mathrm{mol} \mathrm{dm}^{-3}$. Podloga je držana u kontaktu s otopinom $\mathrm{HCl} 15$ min pri $50{ }^{\circ} \mathrm{C} \mathrm{uz}$ umjereno miješanje, isprana destiliranom vodom te uronjena u otopinu $\mathrm{NaOH}$ na 15 min pri $50{ }^{\circ} \mathrm{C}$. Postupak je ponovljen tri puta, nakon čega su podloge ostavljene uronjene $u$ destiliranu vodu. Žarenje podloga provedeno je u trajanju $2 \mathrm{~h}$ pri $500{ }^{\circ} \mathrm{C}$, nakon čega se podloga odmah uranja u otopinu za nanošenje prevlake. Bočice i vijalice su napunjene otopinom, a pločice, mrežice i tkanine uronjene u pripremljenu otopinu. Podloge su označene prema morfologiji ( $\mathrm{p}$ - predmetno stakalce, $\mathrm{m}$ - mrežica, t - tkanina, $b$ - bočica, $v$ - vijalica) i prethodnoj modifikaciji ( $\mathrm{H}$ - hidroliza, Z - žarenje, $\mathrm{O}$ - bez modifikacije), kako je navedeno u tablici 1 .

Kristalizacija se odvijala u sušioniku pri $55{ }^{\circ} \mathrm{C}$ u trajanju $41 \mathrm{~h}$, no u jednom slučaju bilo je potrebno $44 \mathrm{~h}$ da bi došlo do nastajanja slojeva. Stoga je ponovljivost sinteze bez prethodne modifikacije površine ispitana u tri usporedne posude istodobno u trajanju $41 \mathrm{~h}$ (serije $\mathrm{A}, \mathrm{B}, \mathrm{C})$, kao i ponovljenim sintezama u trajanju $41 \mathrm{~h}$ odmah (serije D i E) i u razmaku od 6 mjeseci (serije $F$ i G), kako je navedeno u tablici 2. Svaka serija sastojala se od osam pločica namijenjenih daljnjim ispitivanjima
Tablica 2 - Ponovljivost nanošenja sloja u istim uvjetima te konstanta brzine fotokatalitičke razgradnje 2,5-DHBA na slojevima $\mathrm{ZnO}$

Table 2 - Reproducibility of layer deposition in the same conditions, and the rate constant for the photocatalytic decomposition of 2,5-DHBA on $\mathrm{ZnO}$ layers

\begin{tabular}{c|c|c}
\hline $\begin{array}{c}\text { Uzorak } \\
\text { Sample }\end{array}$ & $\begin{array}{c}m \text { (sloj) } / m \text { (podloga), } \mathrm{mg} / \mathrm{g} \\
m \text { (layer) } / m \text { (substrate), } \mathrm{mg} / \mathrm{g}\end{array}$ & $k / 10^{-3} \mathrm{~min}^{-1}$ \\
\hline $\begin{array}{c}\text { serija A } \\
\text { series A }\end{array}$ & $7,12 \pm 1,90$ & $\begin{array}{c}1,93 \pm 0,05 \\
1,94 \pm 0,05\end{array}$ \\
\hline $\begin{array}{c}\text { serija B } \\
\text { series B }\end{array}$ & $4,68 \pm 0,96$ & $\begin{array}{c}1,41 \pm 0,08 \\
1,38 \pm 0,06\end{array}$ \\
\hline serija C & $4,35 \pm 1,07$ & $\begin{array}{c}\text { nije ispitivano } \\
\text { not investigated }\end{array}$ \\
series C & $5,84 \pm 1,24$ & $\begin{array}{c}2,11 \pm 0,05 \\
1,88 \pm 0,07\end{array}$ \\
\hline $\begin{array}{c}\text { serija D } \\
\text { series D }\end{array}$ & $6,89 \pm 1,41$ & $2,05 \pm 0,05$ \\
\hline $\begin{array}{c}\text { serija E } \\
\text { series E }\end{array}$ & $5,91 \pm 0,62$ & $2,80 \pm 0,14$ \\
\hline $\begin{array}{c}\text { serija F } \\
\text { series F }\end{array}$ & $5,84 \pm 0,95$ & $2,40 \pm 0,09$ \\
\hline serija G & & $2,44 \pm 0,05$ \\
\hline series G & &
\end{tabular}


Nakon nanošenja sloja uzorci su isprani etanolom i osušeni na $60{ }^{\circ} \mathrm{C}$. Odabrani uzorci naknadno su žareni pri $400{ }^{\circ} \mathrm{C}$ 2 h kako bi došlo do transformacije sloja u ZnO. ${ }^{15}$ Podloge su vagane na analitičkoj vagi prije nanošenja prevlake/ prethodne obrade te nakon sušenja sloja. Rezultati su dani u tablicama 1 i 2, usporedivosti radi izraženi kao masa suhoga sloja po gramu podloge.

\subsection{Karakterizacija}

Morfologija nastalih prevlaka ispitana je pretražnom elektronskom mikroskopijom (engl. Scanning Electron Microscopy, SEM) na uređaju Tescan Vega III Easyprobe, s naponom ubrzanja $10 \mathrm{kV}$. Uzorci su prethodno napareni vodljivim slojem zlata i paladija. Sastav slojeva vezanih na podlogu ispitivan je infracrvenom spektroskopskom analizom s Fourierovom transformacijom (FTIR) i ATR detektorom na uređaju Bruker VERTEX 70, u rasponu valnih brojeva $4000-400 \mathrm{~cm}^{-1}$ i s rezolucijom $1 \mathrm{~cm}^{-1}$. Kristalna struktura slojeva vezanih na podlogu određena je rendgenskom difrakcijskom analizom (XRD) na difraktometru Shimadzu XRD 6000 s CuK $\alpha$ zračenjem, u području $3-70^{\circ} 2 \theta$, s korakom od $0,02^{\circ}$ te vremenom zadržavanja $0,6 \mathrm{~s}$.

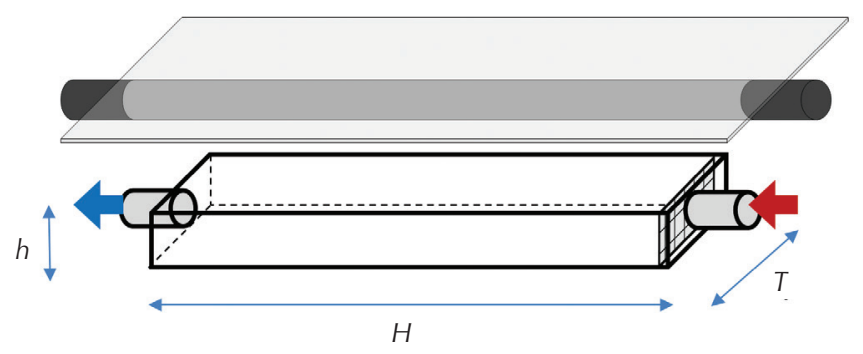

Slika 1 - Shema fotokatalitičkog reaktora: $H=17 \mathrm{~cm}, T=3,9 \mathrm{~cm}$ i $h=1 \mathrm{~cm}$

Fig. 1 - Photocatalytic reactor scheme: $H=17 \mathrm{~cm}, T=3.9 \mathrm{~cm}$, and $h=1 \mathrm{~cm}$
Fotokatalitička aktivnost prevlaka ZnO na predmetnim stakalcima (serije $A-G$ ) ispitivala se razgradnjom modelnog onečišćivala, 2,5-dihidroksibenzojeve kiseline (2,5-DHBA, Sigma-Aldrich) u pločastom reaktoru ukupnog radnog volumena $66 \mathrm{~cm}^{3}$ (slika 1) kroz koji reakcijska smjesa koncentracije $0,20 \mathrm{mmol} \mathrm{dm}^{-3}$ recirkulira konstantnim protokom od $30 \mathrm{ml} \mathrm{min}^{-1}$. Predmetna stakalca sa $\mathrm{ZnO}$ prevlakom smještena su na dnu reaktora. Kao izvor zračenja upotrebljava se UV lampa smještena $3 \mathrm{~cm}$ iznad fotokatalitičkog sloja na dnu reaktora koja osigurava jednoliko osvjetljavanje cijelog reaktorskog prostora. Otopina 2,5-DHBA i prevlake od ZnO izložene su djelovanju UV-zračenja u trajanju od $4 \mathrm{~h}$, te su uzorci otopine uzimani na početku reakcije i u redovitim razmacima za vrijeme odvijanja reakcije. Reakcija se provodila pri sobnoj temperaturi, koja je za vrijeme cijelog ispitivanja varirala između 23,5 i $25^{\circ} \mathrm{C}$, a ne više od $1{ }^{\circ} \mathrm{C}$ tijekom jednog mjernog ciklusa od 4,5 h. Koncentracija 2,5-DHBA određena je pomoću UV-Vis spektrofotometra PerkinElmer Lambda 35 iz apsorbancije otopine pri $320 \mathrm{~nm}$, valnoj duljini apsorpcijskog maksimuma 2,5-DHBA. Baždarni pravci koji određuju ovisnost apsorbancije o koncentraciji konstruirani su iz standardnih otopina u rasponu koncentracija 0,05 - 0,25 $\mathrm{mmol} \mathrm{dm}^{-3}$. Konstanta brzine reakcije degradacije izračunata je iz kinetičkog modela reakcije pseudo-prvog reda.

\section{Rezultati i rasprava}

Sastav i kristalna struktura slojeva odgovaraju očekivanom slojevitom bazičnom cinkovom acetatu, $\mathrm{Zn}_{5}(\mathrm{OH})_{8}\left(\mathrm{CH}_{3} \mathrm{COO}\right)_{2} \cdot 2 \mathrm{H}_{2} \mathrm{O}$. S obzirom na to da je kristalizacija i transformacija toga spoja detaljnije obrađena u prethodnom radu, ${ }^{15}$ ovdje će se naglasiti samo odstupanja od toga sastava i strukture.

\subsection{Utjecaj volumena i dodane vode}

Udvostručenje volumena otopine ne utječe znatnije na morfologiju nastaloga sloja, dok dodatak vode ima zamjetan utjecaj jer nastaje dodatna faza u obliku kuglica (slika 2). XRD difraktogram toga uzorka pokazao je pri-
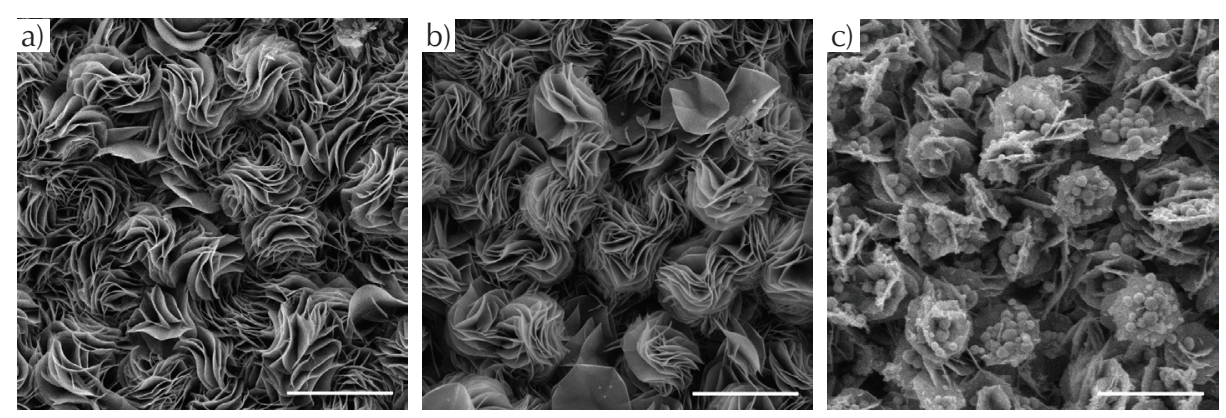

Slika 2 - Morfologija sloja istaloženog (a) pri $55{ }^{\circ} \mathrm{C}$ iz $0,15 \mathrm{M}$ otopine, (b) pri istim uvjetima iz dvostrukog volumena otopine, (c) pri istim uvjetima uz dodatak vode; skala predstavlja $10 \mu \mathrm{m}$

Fig. 2 - Morphology of the layer deposited (a) at $55^{\circ} \mathrm{C}$ from $0.15 \mathrm{M}$ solution, (b) under the same conditions from the double solution volume; (c) under the same conditions with addition of water; scale bar equals $10 \mu \mathrm{m}$ 


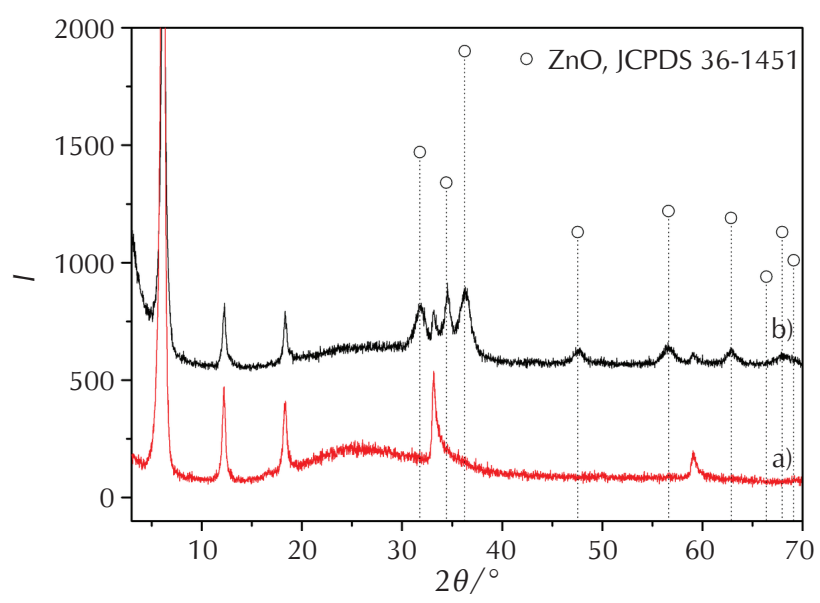

Slika 3 - Difraktogram sloja istaloženog (a) pri $55{ }^{\circ} \mathrm{C}$ iz $0,15 \mathrm{M}$ otopine, svi maksimumi odgovaraju slojevitom bazičnom cinkovom acetatu, (b) pri istim uvjetima uz dodatak vode; karakteristični maksimumi cinkita označeni su okomitim točkastim linijama

Fig. 3 - Diffractogram of the layer deposited (a) at $55{ }^{\circ} \mathrm{C}$ from $0.15 \mathrm{M}$ solution, all maxima correspond to layered basic zinc acetate, (b) under the same conditions with addition of water; characteristic maxima of zincite are marked by vertical dotted lines

sutnost kristalnog cinkita, ZnO (slika 3), dok FTIR spektar pokazuje vrlu istaknutu vrpcu veze $\mathrm{Zn}-\mathrm{O}$ u području $600-400 \mathrm{~cm}^{-1}$ (slika 4).

\subsection{Utjecaj podloge i njezine modifikacije}

Na slikama 5 - 7 uspoređena je morfologija $\mathrm{ZnO}$ na podlogama različite morfologije i stupnja modifikacije. Može se vidjeti da prethodna hidroliza nešto utječe na morfologiju, tj. ponajprije na promjer nastalih "cvjetića" LBZA, koji su primjetno veći na uzorcima $\mathrm{pH}$ i bH, no ne zamjećuje se znatnija razlika kod uzorka $\mathrm{mH}$. To može biti posljedica

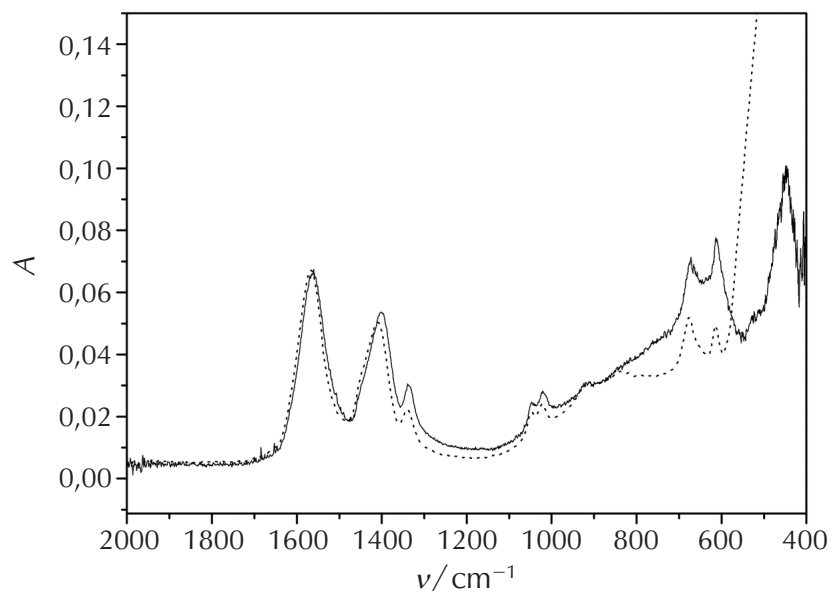

Slika 4 - Infracrveni spektar sloja istaloženog pri $55^{\circ} \mathrm{C}$ iz $0,15 \mathrm{M}$ otopine (puna linija) i pri istim uvjetima uz dodatak vode (crtkana linija)

Fig. 4 - Infrared spectra of the layer deposited at $55{ }^{\circ} \mathrm{C}$ from $0.15 \mathrm{M}$ solution (full line) and under the same conditions with addition of water (dotted line)

prethodne priprave podloga. Naime, pločice i bočice prane su detergentom i vodom te su zadržale izvorni stupanj hidratacije staklene površine (staklena površina u ravnoteži $\mathrm{s}$ atmosferom pokrivena je hidroksilnim skupinama), ${ }^{16}$ dok je mrežica žarena da bi se uklonila organska apretura, koju nije bilo moguće adekvatno ukloniti organskim otapalima (slika 8). Stoga možemo pretpostaviti da je konačna koncentracija hidroksilnih skupina nakon hidrolize bila manja kod mrežice $(\mathrm{mH})$ i tkanine $(\mathrm{tH})$, koja također nije pokazala znatniju promjenu morfologije prevlake. Hidroksilne skupine mogu utjecati na brzinu nukleacije i kristalizacije, te time na konačnu morfologiju nastale prevlake. ${ }^{18,19}$
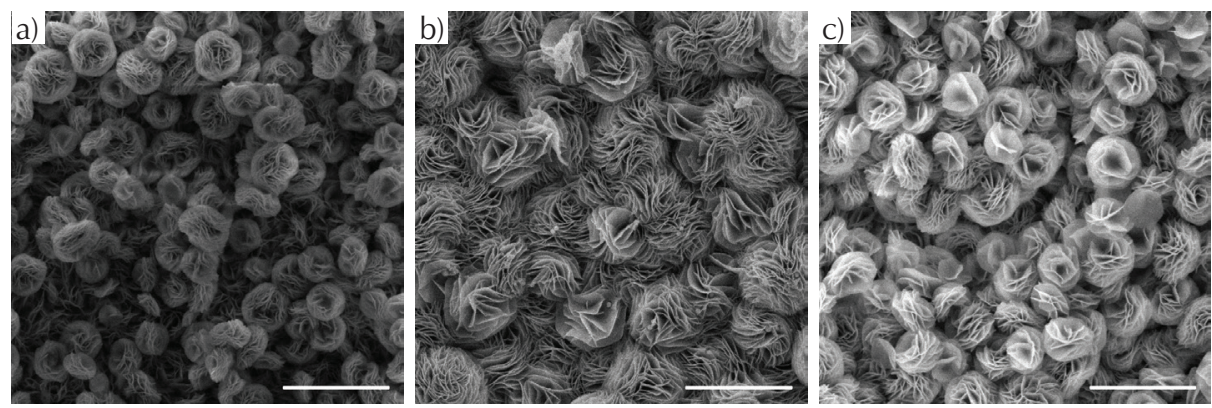

Slika 5 - Prikaz dobivenih slojeva na predmetnim stakalcima:

a) bez prethodne modifikacije - $\mathrm{p} 0$; b) uz prethodnu hidrolizu - $\mathrm{pH}$;

c) uz prethodno žarenje - pZ; skala predstavlja $10 \mu \mathrm{m}$

Fig. 5 - Morphology of the layers obtained on glass slides:

a) without previous modification - $\mathrm{p} 0$; b) previously hydrolysed $-\mathrm{pH}$;

c) previously calcined - pZ; scale bar equals $10 \mu \mathrm{m}$ 

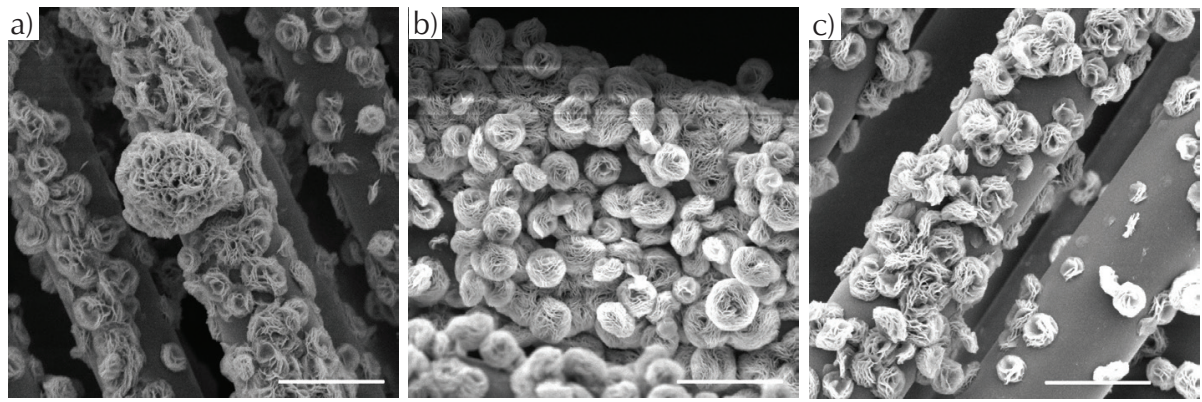

Slika 6 - Prikaz dobivenih slojeva na staklenim mrežicama:

a) bez prethodne modifikacije - $\mathrm{m0}$; b) uz prethodnu hidrolizu - $\mathrm{mH}$;

c) uz prethodno žarenje - mZ; skala predstavlja $10 \mu \mathrm{m}$

Fig. 6 - Morphology of the layers obtained on glass mesh:

a) without previous modification $-\mathrm{m0}$; b) previously hydrolysed $-\mathrm{mH}$;

c) previously calcined $-\mathrm{mZ}$; scale bar equals $10 \mu \mathrm{m}$
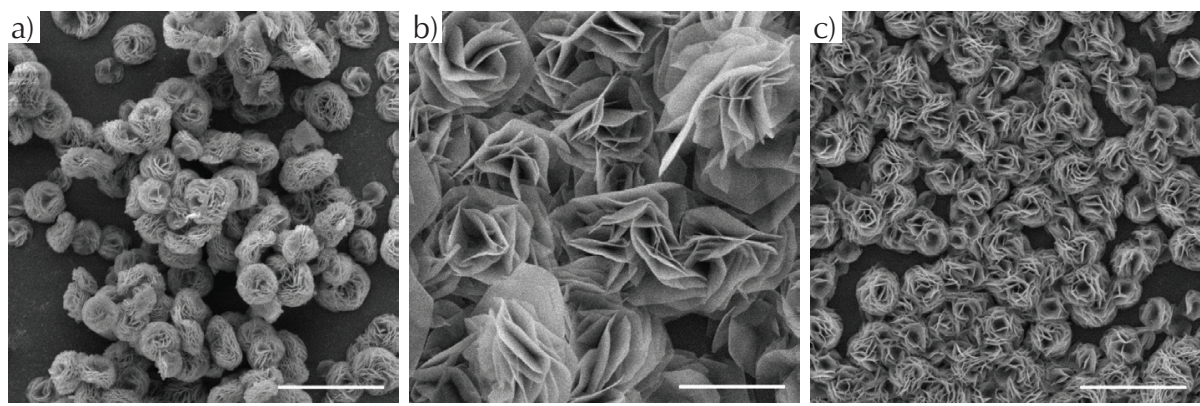

Slika 7 - Prikaz dobivenih slojeva na staklenim bočicama:

a) bez prethodne modifikacije - b0; b) uz prethodnu hidrolizu - bH;

c) uz prethodno žarenje - bZ; skala predstavlja $10 \mu \mathrm{m}$

Fig. 7 - Morphology of the layers obtained on glass bottles:

a) without previous modification - b0; b) previously hydrolysed - $\mathrm{bH}$;

c) previously calcined - bZ; scale bar equals $10 \mu \mathrm{m}$

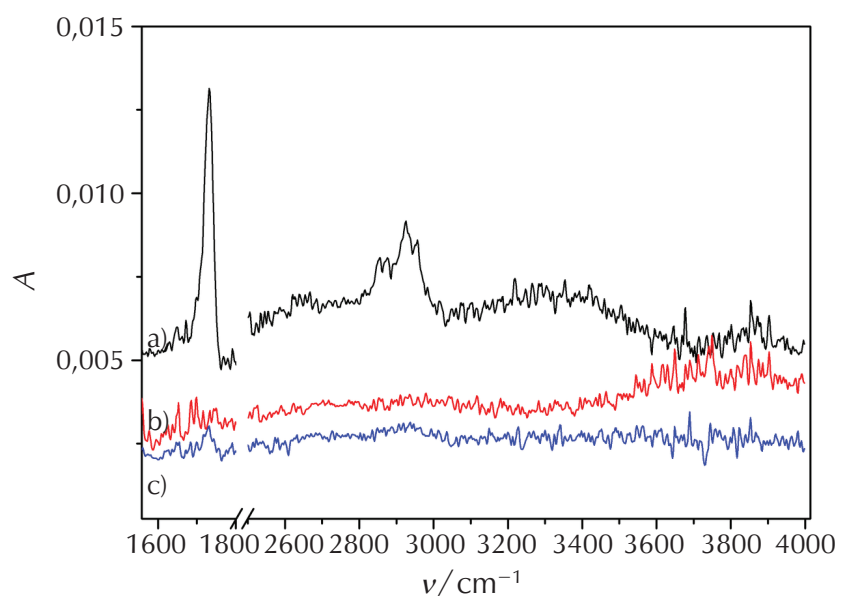

Slika 8 - Infracrveni spektar a) netretirane staklene mrežice s vidljivim vrpcama organske apreture, b) mrežice nakon žarenja pri $400{ }^{\circ} \mathrm{C}$ s uklonjenim svim vrpcama i c) mrežice nakon ispiranja tetrahidrofuranom sa smanjenom, ali još vidljivom vrpcom pri $1732 \mathrm{~cm}^{-1}$

Fig. 8 - Infrared spectra of a) untreated glass mesh with visible bands of the organic sizing; b) mesh after heat treatment at $400{ }^{\circ} \mathrm{C}$ with all sizing bands removed, and c) mesh after washing with tetrahydrofuran with reduced but still visible band at $1732 \mathrm{~cm}^{-1}$
Prethodno žarenje ne utječe primjetno na morfologiju niti pokrivenost površine kod svih uzoraka, što se može vidjeti i iz usporedbe mase prevlaka navedenih u tablici 1 , gdje je nanesena masa za istu morfologiju redovito najniža za uzorke modificirane žarenjem. Stoga ta modifikacija nije ispitivana za sve morfologije podloge.

Hidrolizom staklenih podloga postignuta je veća pokrivenost zakrivljenih površina $(\mathrm{mH}, \mathrm{bH})$ a u pravilu i veća debljina/masa prevlake (tablica 1). Prevlake na prethodno hidroliziranoj površini tkanine bile su deblje i u potpunosti su prekrile površinu (slika 9), no zbog debljine dolazi do pucanja i odvajanja prevlake kako je vidljivo na slici 9 b), što objašnjava i smanjenje mase sloja u tom slučaju. U slučaju vijalica, uskih staklenih posudica, bez prethodne modifikacije nastaje gradijent $\mathrm{u}$ debljini nastale prevlake, s grubljim i debljim slojem na jednom dijelu vijalice (slike 10 a i b), moguće i zbog gradijenta temperature te pojačanog nastajanja sloja na donjem dijelu vijalice. Uz prethodnu hidrolizu nastaje mnogo homogeniji sloj, pa možemo pretpostaviti da povećana koncentracija hidroksilnih skupina pogoduje jednoličnoj heterogenoj nukelaciji uzduž cijele površine vijalice. 

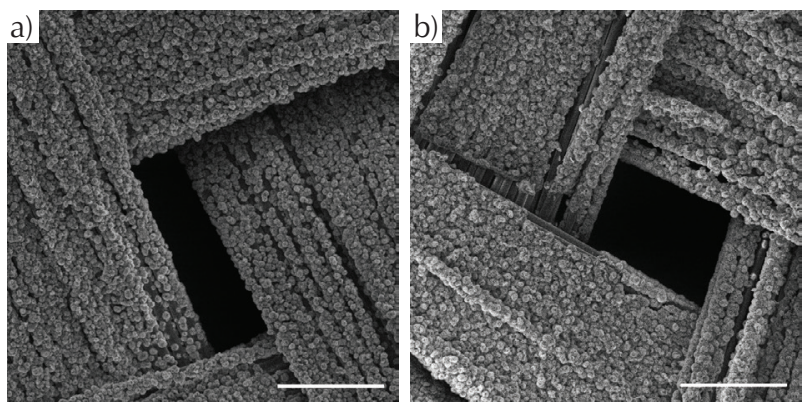

Slika 9 - Prikaz dobivenih slojeva na staklenoj tkanini: a) bez prethodne modifikacije - t0; b) uz prethodnu hidrolizu - tH; skala predstavlja $100 \mu \mathrm{m}$

Fig. 9 - Morphology of the layers obtained on glass fabric: a) without previous modification - t0; b) previously hydrolysed - tH; scale bar equals $100 \mu \mathrm{m}$
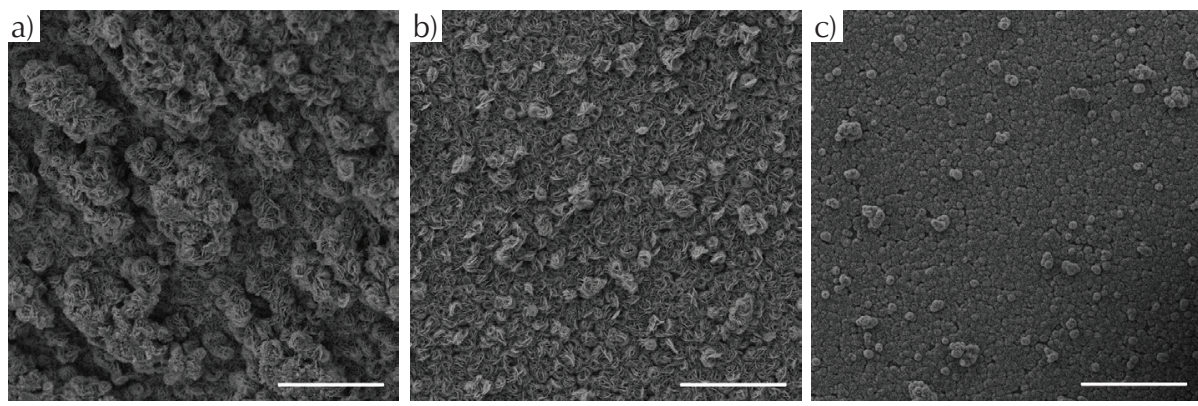

Slika 10 - Prikaz dobivenih slojeva na staklenim vijalicama: a) i b) bez prethodne modifikacije - v0, c) uz prethodnu hidrolizu - vH; skala predstavlja $100 \mu \mathrm{m}$

Fig. 10 - Morphology of the layers obtained on glass vials: a) and b) without previous modification - v0; c) previously hydrolysed - vH; scale bar equals $100 \mu \mathrm{m}$
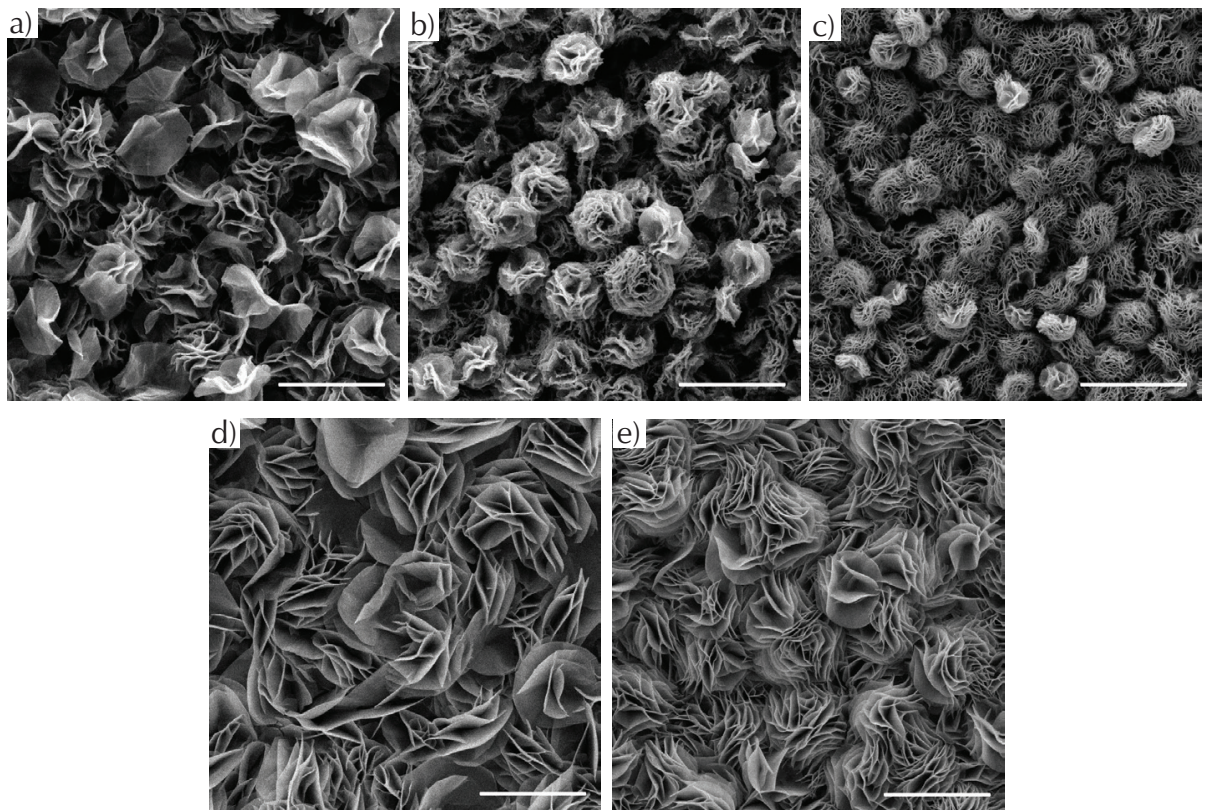

Slika 11 - Razlika u morfologiji slojeva nastalih u istim uvjetima; usporedno: a) serija A, b) serija $B, c)$ serija $C$, te u razmaku od 6 mjeseci: d) serija $F$, e) serija $G$; skala predstavlja $10 \mu \mathrm{m}$

Fig. 11 - Differences in morphology of the layers formed under the same conditions; parallel synthesis: a) series A, b) series B, c) series $C$; 6 months' time difference in synthesis: d) series $F$, e) series $G$; scale bar equals $10 \mu \mathrm{m}$ 


\subsection{Ponovljivost nanošenja prevlaka}

Na slici 11 prikazana je razlika morfologija serija prevlaka koje su sve pripravljene $u$ istim nominalnim uvjetima, ali su sinteze provedene ili na različitim položajima u sušioniku (serije A - C) ili u različitim vremenima (serije D - G). Razlika u morfologiji izraženija je u slučaju duljeg protoka vremena između sinteza, što može biti posljedica fluktuacija sastava kemikalija - u međuvremenu je bilo potrebno nabaviti dodatne kemikalije. No vidljiva je $\mathrm{i}$ određena razlika između serija A, B i C koje su rađene usporedno iz iste početne otopine, što se može pripisati gradijentu temperature unutar sušionika, pa time i unutar posuda s otapalom: otapalo nije bilo moguće miješati tijekom sinteze, pa je vrlo vjerojatno došlo do gradijenata temperature i koncentracije prilikom sinteze. Iz tablice 2 može se vidjeti i varijacija u masi nanesenih prevlaka, unutar pojedine serije te između serija. Ponovljivost je bolja pri uzastopnim nego pri usporednim nanošenjima, što je zorno prikazano na slici 12.

Varijacije u morfologiji utječu i na kinetiku razgradnje 2,5-DHBA, kako se može vidjeti sa slike 13 i tablice 2 , te je i tu razlika najizraženija kod usporedne priprave (A i B), a manja kod slijednih priprava ( $\mathrm{i} D, E)$, iako je zamjetna razlika kod prevlaka koje su pripravljene u razmaku od 6 mjeseci (D i E naspram F i G). Serija B ima za 50 \% manju, dok serija F ima 34 \% veću konstantu brzine degradacije od prosjeka $\left(2,09 \cdot 10^{-3} \mathrm{~min}^{-1}\right)$. Nema očitog utjecaja debljine sloja na efikasnost fotorazgradnje ispitivanog zagađivala, vjerojatno zato što niti svjetlost niti vodena otopina ne mogu prodrijeti duboko u naneseni sloj.

\section{Zaključak}

Ispitan je utjecaj različitih parametara priprave na morfologiju i debljinu LBZA prevlaka na staklu. Pokazalo se da dodatak vode može dovesti do taloženja kuglastih tvorevina $\mathrm{ZnO}$, što ne pogoduje cilju dobivanja cvjetaste strukture velike relativne površine. Prevlake se uspješno nanose na površine različitih morfologija, a prethodna hidroliza pod-

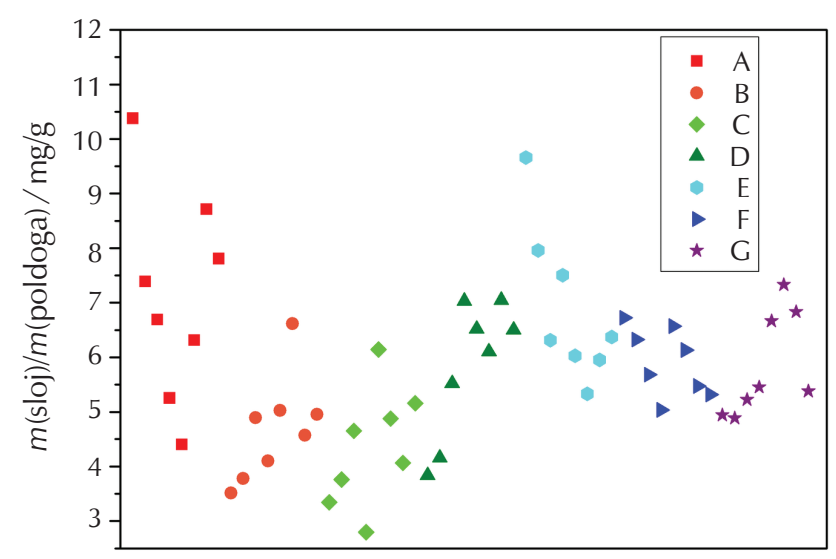

Slika 12 - Raspon istaloženih masa slojeva za serije A - G. Ponovljivost nanošenja usporednih serija $\mathrm{A}-\mathrm{C}, \mathrm{mg} / \mathrm{g}$ : $5,38 \pm 1,82$ (min.: 2,80, maks.: 10,38). Ponovljivost nanošenja uzastopnih serija D - G, mg/g: 6,12 $\pm 1,14$ (min.: 3,84, maks.: 9,66).

Fig. 12 - Range of deposited layer masses for series A - G. Repeatability of in-parallel-deposited series A - C, $\mathrm{mg} / \mathrm{g}: 5.38 \pm 1.82$ (min.: 2.80, max.: 10.38). Repeatability of sequentially deposited series $\mathrm{D}-\mathrm{G}, \mathrm{mg} / \mathrm{g}$ : $6.12 \pm 1.14$ (min.: 3.84, $\max .:$ 9.66).

loge pokazala se povoljnom za dobivanje debljih i čvršće vezanih slojeva. No postupak priprave znatno je osjetljiv na gradijente temperature i koncentracije koji nastaju prilikom priprave većeg broja uzoraka, što čini prevlačenje većih površina zahtjevnijim. Fotokatalitička aktivnost slojeva dobivenih u nominalno jednakim uvjetima varira i do $50 \%$, bez jasne pravilnosti.

\section{ZAHVALA}

Ovaj rad djelomice je financirala Zaklada HAZU preko projekta Optimiranje uvjeta priprave fotokatalitički aktivnih ZnO čestica i prevlaka sol-gel postupkom. Autori zahvaljuju prof. dr. sc. Mutavdžić Pavlović na pomoći oko UV-Vis spektroskopije.

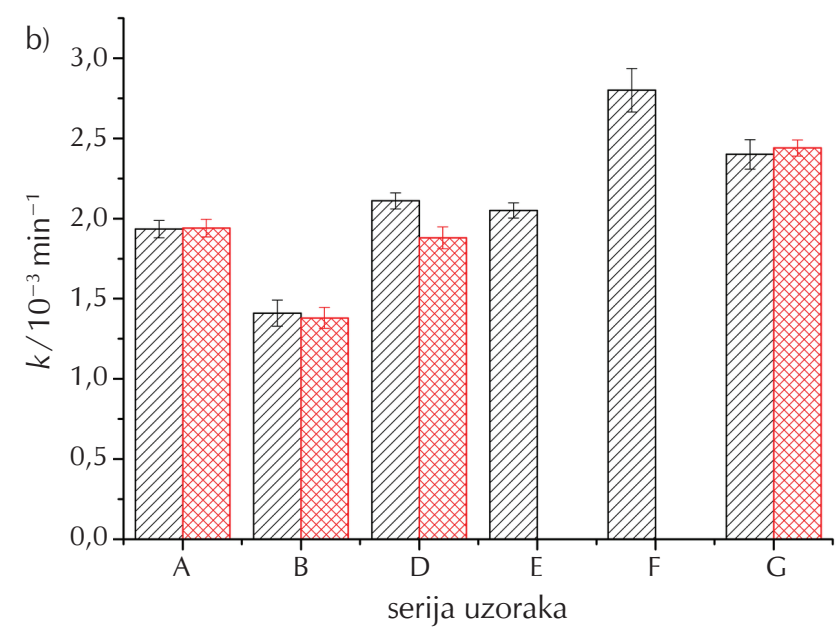

Slika 13 - Usporedba (a) smanjenja koncentracije 2,5-DHBA i (b) odgovarajućih konstanti degradacije (kinetika pseudo-prvoga reda) za ispitivane serije $\mathrm{ZnO}$ prevlaka

Fig. 13 - Comparison of (a) 2,5-DHBA concentration decrease, and (b) corresponding degradation rate constants (pseudo-first rate kinetics) for the studied series of $\mathrm{ZnO}$ layers 


\section{Literatura \\ References}

1. Z. L. Wang, Zinc oxide nanostructures: growth, properties and applications, J. Phys. Condens. Mater. 16 (2004) R829R858, doi: https://doi.org/10.1088/0953-8984/16/25/R01.

2. F. Xu, L. Sun, Solution-derived $\mathrm{ZnO}$ nanostructures for photoanodes of dye-sensitized solar cells, Energy Environ. Sci. 4 (2011) 818-841, doi: https://doi.org/10.1039/c0ee00448k.

3. N. Talebian, M. R. Nilforoushan, N. Maleki, Ultraviolet to visible-light range photocatalytic activity of $\mathrm{ZnO}$ films prepared using sol-gel method: the influence of solvent, Thin Solid Films 527 (2013) 50-58, doi: https://doi.org/10.1016/j. tsf.2012.11.138.

4. K. M. Lee, C. W. Lai, K. S. Ngai, J. C. Juan, Recent developments of zinc oxide based photocatalyst in water treatment technology: a review, Water. Res. 88 (2016) 428-448, doi: https://doi.org/10.1016/j.watres.2015.09.045.

5. E. Hosono, S. Fujihara, T. Kimura, Synthesis, structure and photoelectrochemical performance of micro/nano-textured ZnO/eosin Y electrodes, Electrochim. Acta 49 (2004) 2287 2293, doi: https://doi.org/10.1016/j.electacta.2004.01.009.

6. E. Hosono, S. Fujihara, T. Kimura, H. Imai, Growth of layered basic zinc acetate in methanolic solutions and its pyrolytic transformation into porous zinc oxide films, J. Colloid Interface. Sci. 272 (2004) 391-398, doi: https://doi. org/10.1016/j.jcis.2003.10.005.

7. E. Hosono, S. Fujihara, T. Kimura, H. Imai, Non-basic solution routes to prepare $\mathrm{ZnO}$ nanoparticles, J. Sol-Gel Sci. Technol. 29 (2004) 71-79, doi: https://doi.org/10.1023/B:JSST.0000023008.14883.1e.

8. S. Fujihara, E. Hosono, T. Kimura, Fabrication of porous metal oxide semiconductor films by a self-template method using layered hydroxide metal acetates, J. SolGel Sci. Technol. 31 (2004) 165-168, doi: https://doi. org/10.1023/B:JSST.0000047980.69279.9b.

9. T. Biswick, W. Jones, A. Pacula, E. Serwicka, J. Podobinski, The role of anhydrous zinc nitrate in the thermal decomposition of the zinc hydroxy nitrates $\mathrm{Zn}_{5}(\mathrm{OH})_{8}\left(\mathrm{NO}_{3}\right)_{2} \cdot 2 \mathrm{H}_{2} \mathrm{O}$ and $\mathrm{ZnOHNO} \cdot \mathrm{H}_{2} \mathrm{O}$, J. Solid State Chem. 180 (2007) $1171-$ 1179, doi: https://doi.org/10.1016/j.jssc.2007.01.012

10. N. Audebrand, J. P. Auffredic, D. Louer, X-ray diffraction study of the early stages of the growth of nanoscale zinc oxide crystallites obtained from thermal decomposition of four precursors, Chem. Mater. 10 (1998) 2450-2461, doi: https://doi.org/10.1021/cm980132f.

11. M. Yao, P. Hu, Y. Cao, W. Xiang, X. Zhang, F. Yuan, Y. Chen, Morphology-controlled ZnO spherical nanobelt-flower arrays and their sensing properties, Sensor. Actuator. B Chem. 177 (2013) 562-569, doi: https://doi.org/10.1016/j. snb.2012.11.088.

12. Z. Xia, Y. Wang, Y. Fang, Y. Wan, W. Xia, J. Sha, Understanding the origin of ferromagnetism in $\mathrm{ZnO}$ porous microspheres by systematic investigations of the thermal decomposition of $\mathrm{Zn}_{5}(\mathrm{OH})_{8} \mathrm{Ac}_{2} \cdot 2 \mathrm{H}_{2} \mathrm{O}$ to $\mathrm{ZnO}$, J. Phys. Chem. C 115 (2011) 14576-14582, doi: https://doi.org/10.1021/jp202849c.

13. H. Lu, S. Wang, L. Zhao, J. Li, B. Dong, Z. Xu, Hierarchical $\mathrm{ZnO}$ microarchitectures assembled by ultrathin nanosheets: hydrothermal synthesis and enhanced photocatalytic activity, J. Mater. Chem. 21 (2011) 4228-4234, doi: https://doi. org/10.1039/c0jm03390a.

14. Y. Fang, Z. Xia, F. Yu, J. Sha, Y. Wang, W. Zhou, Formation mechanism of hollow microspheres consisting of $\mathrm{ZnO}$ nanosheets, CrystEngComm 14 (2012) 8615-8619, doi: https:// doi.org/10.1039/c2ce26354h.

15. J. Macan, M. Ivanko, I. Bukovčan, I. Grčić, A. Gajović, Stable hierarchical $\mathrm{ZnO}$ structures for photocatalytic degradation of 2,5-dihydroxybenzoic acid, Mater. Sci. Semiconduct. Process. 97 (2019) 48-55, doi: https://doi.org/10.1016/j. mssp.2019.03.006.

16. X. M. Liu, J. L. Thomason, F. R. Jones, The concentration of hydroxyl groups on glass surfaces and their effect on the structure of silane deposits, u: K. L. Mittal (ur.) Silanes and Other Coupling Agents, Vol. 5, Koninklijke Brill NV, Leiden, 2009., str. 25-38.

17. G. Xiong, H. Luo, J. Zhang, J. Jin, Y. Wan, Synthesis of ZnO by chemical bath deposition in the presence of bacterial cellulose, Acta Metall. Sin. (Engl. Lett.) 27 (2014) 656-662, doi: https://doi.org/10.1007/s40195-014-0088-5.

18. H. Kim, J. Hong, C. Kim, E.-Y. Shin, M. Lee, Y.-Y. Noh, B. Park, I. Hwang, Impact of hydroxyl groups boosting heterogeneous nucleation on perovskite grains and photovoltaic performances, J. Phys. Chem. C 122 (2018) 16630-16638, doi: https://doi.org/10.1021/acs.jpcc.8b05374.

19. E. Navarrete, C. Heyser, R. Henríquez, R. Schrebler, R. Córdova, E. Muñoz, Changes in the surface activity of n-Si after interaction with hydroxyl radicals, J. Electroanal. Chem. 727 (2014) 39-46, doi: https://doi.org/10.1016/j.jelechem.2014.05.019.

\section{SUMMARY \\ Deposition of Photocatalytically Active ZnO Layers on Substrates of Varying Geometries \\ Jelena Macan, ${ }^{a},{ }^{*}$ Monika Kovačević, ${ }^{a}$ Maja Lipovski, ${ }^{a}$ Mihovil Medić, and Ivana Grčićb}

Preparation of photocatalytically active $\mathrm{ZnO}$ layer by chemical bath deposition was investigated. Layers of layered basic zinc acetate (LBZA) were successfully deposited on substrates of varying morphologies, and the substrate hydrolysis led to formation of thicker and better adhering layers. However, the process was quite sensitive to variations in conditions, which makes coating of larger surfaces more challenging. Photocatalytic activity of $\mathrm{ZnO}$ layers obtained from LBZA by calcining had poor reproducibility, varying up to $50 \%$ without obvious regularity.

\section{Keywords}

Chemical bath deposition, microstructure, photocatalytic decomposition, surface modification, zinc oxide

a University of Zagreb, Faculty of Chemical Engineering and Technology, Marulićev trg 19, HR-10 000 Zagreb, Croatia

${ }^{\mathrm{b}}$ University of Zagreb, Faculty of Geotechnical Engineering,

Hallerova aleja 7, HR-42 000 Varaždin, Croatia
Original scientific paper Received April 11, 2019 Accepted July 4, 2019 